\title{
An Analysis on Tourism Potency and the Community Readiness in Developing Berancah as a Tourism Village
}

\author{
M. Sabri, Diah Paramita Sari \\ English Department \\ State Polytechnic of Bengkalis \\ Riau, Indonesia
}

\begin{abstract}
The aim of this research is to analyze the tourism potency and the community readiness of Berancah Village in order to know the feasibility of the village to be developed into a tourism village. The method used for this research is a descriptive qualitative research. The data collected through direct observation towards the tourism objects and all the supporting facilities, and also through several interviews with related stakeholders. To analyze the community readiness, a Participatory Rural Appraisal (PRA) and series of questionnaire were given to the villagers. Based on this research, it is concluded that Berancah Village is feasible to be developed into a tourism village with a positive support from the community.
\end{abstract}

Keywords—-potency, tourism village, community readiness

\section{INTRODUCTION}

Tourism Village Program is now beginning to become a trend for local governments in improving the economy of rural communities in an effort to reduce poverty. The concept of village tourism makes that village known so that the village has a market value and able to stimulate the economy of the village community.

Desa Berancah in Bantan Sub-district, Bengkalis Regency, Riau is a newly expanded village several years ago. Just like a new village, the government and the people of Desa Berancah are continuing to improve themselves to be able to compete with other villages that have already been built.

The village which is about 30 minutes to the northeast of Bengkalis City has begun to cooperate with various stakeholders including educational institutions such as Bengkalis State Polytechnic in terms of community service and research in order to recognize, explore and optimize the potential in the village.

The village which is about 30 minutes to the northeast of Bengkalis City has begun to cooperate with various stakeholders including educational institutions such as Bengkalis State Polytechnic in terms of community service and research in order to recognize, explore and optimize the potential in the village.

Based on pre observation, the village inhabited by approximately 756 heads of families has several potential natural tourist attractions that can be developed such as 500 ha of mangrove forests, rain-fed rice fields around 50 ha, and cultural tourism potential and community wisdom such as art Reog and Barongsai. However, to developed Desa Berancah become tourist village, several other factors including accessibility, supporting facilities and community readiness are needed to be further analyzed.

Based on the problems above, the authors are interested to analyze the potential of tourism objects and readiness of Berancah Village to be developed into a tourist village. The purpose of this study is to analyze the potential of natural and cultural attractions, supporting facilities and readiness of Berancah Village community and also to know its level of feasibility to be developed into a tourist village.

\section{REVIEW OF RELATED LITERATURE}

\section{A. Tourism}

Directorate General of PHKA explains that the program of sustainable natural tourism development can be done by looking at several factors including: Development of object location (Potential ODTWA) [1], Object development activities Supporting facilities, Visitors' environment, Management and service, and Nature tourism activities.

\section{B. Tourism Component}

According to Yoeti, there are 3 components of tourism, they are [2]

1) Attraction: Tourist attraction is a place of tourist destination. This attraction can be divided into:

- Site attraction (interesting place, place with comfortable chair, beautiful scenery and historic place)

- Event attraction (places related to tourism, conferences, sports events fairs, festivals and others)

2) Accessibility: Soekadijo states that accessibility is the availability of transportation to tourist destinations and easiness in reaching tourist destinations either in geographical distance or speed of travel power [3]. Accessibility in tourist 
destinations is influenced by road conditions, freight rates, vehicle type, transportation network, and travel time.

3) Facilities: Soekadijo defines the means of tourism infrastructure as follows: "Infrastructure (infrastructure) is physical construction, such as power plants, health facilities and ports. The suprastructure is everything that is built by utilizing the infrastructure" [3].

4) Community readiness: Hartanti in Sawitri explains that humans have two potentials. Physical potential is a physical being of man, whereas human potential is anything that does not appear physically [4]. Human potential consists of intellectual abilities that produce something innovative as a result of education, training and experience processes, as well as interaction with the environment.

\section{METHOD OF RESEARCH}

The location of the research was in Brancah Village, Bantan District, Bengkalis Regency, Province Riau. This research used descriptive research method that attempt to describe the situation that happened in the field. The sample selection for this research was done through a purposive sampling that is the sampling method which was based on the research objectives. The respondents of this research consisted of the head of the village, religious figures, community figures, and people of Berancah Village, Bantan District, Bengkalis.

The data were collected by primary data and secondary data. Primary data was obtained from the observation, interview, and questionnaire. While secondary data was collected through Brancah Village Government, Bantan District, and Tourism and Culture Office of Bengkalis Regency.

\section{A. Primary Data}

1) Observation of tourism object: The method done was direct observation in Brancah Village and Manggrove Forest. It was continued by interviewing the Village Head and community leaders.

2) Community readiness analysis: The data collection used in this analysis was the questionnaire given to the community around the village of Brancah. It aimed to determine the readiness of the community in the development of the village of Brancah as a tourist village.

\section{B. Secondary Data}

Secondary data obtained through literature study from various reference sources.

\section{1) Data analysis technique:}

a) Analysis of tourist object: The object and attractions that had been collected were analyzed based on the assessment criteria in the guidelines for the Analysis of Regional Objects and Natural Attraction of the Director General of PHKA in 2003 in accordance with the values determined for each criterion. The sum of values for one ODTWA assessment criterion can be calculated by the following equation [1]:

$$
S=N \times B
$$

Note:

$\mathrm{S}=$ score / value of a criterion

$\mathrm{N}=$ number of element values on criteria

$\mathrm{B}=$ weight of value

The feasibility index of an ecotourism area is as follows:

- Feasibility $>66.6 \%$ : feasible to develop, with criteria of a tourist area with high potential, facilities and infrastructure based on established parameters and supported by adequate accessibility.

- Feasibility level $33.3 \%$ - $66.6 \%$ : not yet feasible to develop, with criteria of a tourist area that has potential, suggestions and infrastructure that are based on established parameters and supported by adequate accessibility.

- Feasibility level < 33.3\%: not feasible to develop, with criteria of a tourist area with low potential, facilities and infrastructure based on established parameters and inadequate accessibility.

TABLE I. ASSESSMENT CRITERIA OF OBJECT AND NATURE TOURISM (DIRJEN PHKA 2013)

\begin{tabular}{|c|c|c|c|c|c|c|}
\hline \multirow{2}{*}{ No } & \multirow{2}{*}{$\begin{array}{c}\text { Element/ } \\
\text { sub element }\end{array}$} & \multicolumn{5}{|c|}{ Value } \\
\hline & & 5 & 4 & 3 & 2 & 1 \\
\hline 1. & $\begin{array}{l}\text { The Uniqueness of natural } \\
\text { resources:Flora, } \\
\text { Fauna,Beaches,Mangrove } \\
\text { Forest }\end{array}$ & 30 & 25 & 20 & 15 & 10 \\
\hline 2. & $\begin{array}{l}\text { The number of natural } \\
\text { resources } \\
\text { prominent: } \text { River,Water,Natural } \\
\text { phenomena }\end{array}$ & 30 & 25 & 20 & 15 & 10 \\
\hline 3. & $\begin{array}{l}\text { Natural tourism activities that } \\
\text { can be done: } \\
\text { Enjoy the natural beauty, } \\
\text { Sight seeing for flora and } \\
\text { fauna, Trekking, Research, } \\
\text { Camping }\end{array}$ & 30 & 25 & 20 & 15 & 10 \\
\hline 4. & $\begin{array}{l}\text { Cleanliness of tourist location: } \\
\text { Industry, The crowded streets } \\
\text { Settlements, } \\
\text { Trash, } \\
\text { Vandalism }\end{array}$ & 30 & 25 & 20 & 15 & 10 \\
\hline 5. & $\begin{array}{l}\text { Convenience } \\
\text { Clean and cool air, Far from } \\
\text { the strong odors,Far from the } \\
\text { crowd, No intrusive traffic, } \\
\text { Good service for visitors }\end{array}$ & 30 & 25 & 20 & 15 & 10 \\
\hline
\end{tabular}

Attraction Assessment Criteria (6 Scale) 
TABLE II. ACCESSBILITy AsSESSMENT CRITERIA (5 SCALE)

\begin{tabular}{|l|l|l|l|l|l|}
\hline No & $\begin{array}{l}\text { Element/sub } \\
\text { element }\end{array}$ & \multicolumn{4}{|c|}{ Value } \\
\hline 1. & $\begin{array}{l}\text { Road } \\
\text { Condition }\end{array}$ & $\begin{array}{l}\text { Good } \\
30\end{array}$ & $\begin{array}{l}\text { Enough } \\
25\end{array}$ & $\begin{array}{l}\text { Average } \\
20\end{array}$ & $\begin{array}{l}\text { Bad } \\
15\end{array}$ \\
\hline 2. & $\begin{array}{l}\text { The Distance } \\
\text { from the city }\end{array}$ & $\begin{array}{l}<\mathrm{km} \\
30\end{array}$ & $\begin{array}{l}5-10 \\
\mathrm{~km} \\
25\end{array}$ & $\begin{array}{l}10-15 \\
\mathrm{~km} \\
20\end{array}$ & $\begin{array}{l}>15 \mathrm{~km} \\
15\end{array}$ \\
\hline 3. & $\begin{array}{l}\text { Travelling } \\
\text { time from the } \\
\text { city }\end{array}$ & $\begin{array}{l}1-2 \\
\text { jam } \\
30\end{array}$ & $\begin{array}{l}2-3 \mathrm{jam} \\
25\end{array}$ & $\begin{array}{l}3-4 \mathrm{jam} \\
20\end{array}$ & $\begin{array}{l}>5 \mathrm{jam} \\
15\end{array}$ \\
\hline
\end{tabular}

TABLE III. SUPPORTING FACILITIES AND INFRASTRUCTURE ASSESSMENT CRITERIA (3 SCALE)

\begin{tabular}{|l|l|c|c|c|c|c|}
\hline \multirow{2}{*}{ No } & \multirow{2}{*}{ Element/sub element } & \multicolumn{5}{|c|}{ Numbers } \\
\cline { 3 - 7 } & & $\mathbf{2} 4$ & $\mathbf{3}$ & $\mathbf{2}$ & $\mathbf{1}$ & \multicolumn{1}{|c|}{ No } \\
\hline 1. & $\begin{array}{l}\text { Facilities: } \\
\text { Shop } \\
\text { Banks } \\
\text { Markets } \\
\text { Souvenirs shop } \\
\text { Restaurants }\end{array}$ & 30 & 25 & 20 & 15 & 10 \\
\hline 2. & $\begin{array}{l}\text { Infrastructures: } \\
\text { Post Office } \\
\text { Health center } \\
\text { Drinking water network } \\
\text { Electric network } \\
\text { Phone network }\end{array}$ & 50 & 40 & 30 & 20 & 10 \\
\hline
\end{tabular}

\section{RESULTS AND DISCUSSION}

\section{A. The Assessment of Natural Tourism Objects}

The assessment on tourism objects in Berancah Village was done through direct observation towards all the potential natural tourism resources available in the village. The components assessed including the attraction, accessibility, and supporting facilities infrastructure available in the village.

1) Attraction: Attraction is usually the main reason why the tourists do their visits. The attraction can include the uniqueness of the nature, outstanding natural resources, tourism activities that can be done, the cleanliness and the comfort.

TABLE IV. RESULTS ON ATTRACTION

\begin{tabular}{|c|c|c|c|c|}
\hline Component & Object & Scale* & Score & Total $* *$ \\
\hline $\begin{array}{l}\text { Uniqueness } \\
\text { of Nature }\end{array}$ & Flora & 6 & 10 & 60 \\
\hline $\begin{array}{l}\text { Outstanding } \\
\text { Natural } \\
\text { Resources }\end{array}$ & $\begin{array}{l}\text { River, Mangrove, Rice } \\
\text { field }\end{array}$ & 6 & 20 & 120 \\
\hline $\begin{array}{l}\text { Tourism } \\
\text { activity can } \\
\text { be done }\end{array}$ & $\begin{array}{l}\text { Sightseeing, tracking, } \\
\text { camping, } \\
\text { bicycling, bird watching }\end{array}$ & 6 & 30 & 180 \\
\hline Cleanliness & $\begin{array}{l}\text { Far from: industries, } \\
\text { traffic, rubbish, vandalism }\end{array}$ & 6 & 30 & 180 \\
\hline Comfort & $\begin{array}{l}\text { Fresh and clean air, free } \\
\text { from disturbing smell and } \\
\text { noise, friendly people }\end{array}$ & 6 & 30 & 180 \\
\hline Score & & & 120 & 720 \\
\hline
\end{tabular}

* Based on assessment criteria from Dirjen PHKA 2003 for attraction.

** Sum of scale and score.
2) Accessibility: Accessibility is the factor that makes the visitors easier to get to the destination from their original residence. Some important components in assessing the accessibility including the condition of the roads, the distance from the central city to the destination and also the travelling time needed to get to the destination.

TABLE V. RESUlt ON ACCESSIBILITY

\begin{tabular}{|l|l|l|l|l|}
\hline \multicolumn{1}{|c|}{ Component } & Description & Scale* $^{*}$ & Score & Total** \\
\hline Roads condition & good & 5 & 25 & 125 \\
\hline $\begin{array}{l}\text { Distance from } \\
\text { central city }\end{array}$ & $>15 \mathrm{~km}$ & 5 & 15 & 75 \\
\hline $\begin{array}{l}\text { Travelling time } \\
\text { from the central } \\
\text { city }\end{array}$ & 30 minutes & 5 & 30 & 150 \\
\hline Score & & & 70 & 350 \\
\hline
\end{tabular}

3) Facility and infrastructure: Facilities and infrastructure are two important factors needed by the visitors to make their visit or stay more comfortable. Facilities are all factors that can make the visitors directly enjoy the tourism objects, including: stalls/stores, restaurants, places for worship, central for souvenirs, etc. Infrastructure including all the factors that indirectly support the tourism activities, such as: health center, electricity, police office, etc.

The following table 4 is the assessment result on the facility:

TABLE VI. RESULT ON FACILITIES AND INFRASTRUCTURE

\begin{tabular}{|l|l|l|l|l|}
\hline Component & \multicolumn{1}{|c|}{ Description } & Scale* & Score & Total** \\
\hline Facilities & $\begin{array}{l}\text { Stalls/stores, for } \\
\text { places f } \\
\text { worship }\end{array}$ & 3 & 30 & 90 \\
\hline $\begin{array}{l}\text { Infra- } \\
\text { structure }\end{array}$ & $\begin{array}{l}\text { Health center, } \\
\text { roads and } \\
\text { bridges, } \\
\text { electricity, } \\
\text { radio/television } \\
\text { and phone cell } \\
\text { network, etc }\end{array}$ & 3 & 50 & 150 \\
\hline Score & * Based on assessment criteria from Dirjen PHKA 2003 for attraction.
\end{tabular}

4) The overall result on assessment of natural tourism objects of berancah village: The overall assessment result on natural tourism objects in Berancah Village can be seen in the following table 7 :

TABLE VII. OVERALL ASSESSMENT RESULT ON THE FEASIBILITY OF BERANCAH VILlaGE TO BE A TOURISM VILlaGE

\begin{tabular}{|l|l|l|l|l|l|l|}
\hline Component & Scale & $\begin{array}{c}\text { Value } \\
*\end{array}$ & $\begin{array}{c}\text { Score } \\
* *\end{array}$ & $\begin{array}{c}\text { Max } \\
\text { Score } \\
* * * *\end{array}$ & $\begin{array}{c}\text { Index (\%) } \\
* * * *\end{array}$ & Feasibility \\
\hline Attraction & 6 & 120 & 720 & 900 & 80.00 & Feasible \\
\hline Accessibility & 5 & 70 & 350 & 450 & 77.77 & Feasible \\
\hline $\begin{array}{l}\text { Facilities and } \\
\text { Infrastructure }\end{array}$ & 3 & 80 & 240 & 300 & 80.00 & Feasible \\
\hline \multicolumn{8}{|c|}{} & *Assessment result on natural tourism objects \\
$* *$ Multiplication of scale and value \\
$* * *$ Highest score for each criteria
\end{tabular}


From the above table, it can be concluded that based on the potency of its natural tourism objects, Berancah Village is 'Feasible' to be developed as a tourism village with the percentage of $79.25 \%$. For both attraction and also facilities and infrastructures aspects, Berancah Village is categorized feasible with the score of $80.00 \%$. For the accessibility, Berancah Village is also feasible for the development of tourism with the score of $77.77 \%$.

\section{B. The Analyses on Community Readiness in Developing Berancah as a Tourism Village}

Berancah Village, Bantan Sub district, Bengkalis Regency of Riau Province is located about $25 \mathrm{~km}$ from the central city of Bengkalis. With totally 2.634 population, the people of this village live harmony with their tradition of respect, helping to one another and friendliness.

For this time, Berancah Village cannot be said as a tourism village because, even though it has all the natural tourism potency needed for the tourism but it has not yet managed for the purpose of tourism. The potency will be very promising if it is managed seriously with well-organized planning. Therefore, the government and the community need to work together to discuss about the plans to develop their village to become a community based tourism village. The analyses on the community readiness in developing Berancah Village to become a tourism village was done through a Participatory Rural Appraisal (PRA).

Through this analyses, whole community elements were involved together in series of discussions to analyze the potency they have and the problem they face in their planning to develop Berancah Village to become a tourism village.

\section{TABLE VIII. PRA RESULT ON COMMUNITY READINESS IN DEVELOPING} TOURISM VILLAGE

\begin{tabular}{|l|l|l|}
\hline \multicolumn{1}{|c|}{ Aspect } & \multicolumn{1}{|c|}{ Condition } & \multicolumn{1}{|c|}{ Solution } \\
\hline Economy & $\begin{array}{l}\text { The village received fund from } \\
\text { government yearly. However, the } \\
\text { number is still limited. }\end{array}$ & $\begin{array}{l}\text { Making } \\
\text { effectiveness and } \\
\text { efficiency } \\
\text { Already has view home industries } \\
\text { (e.q. food, handicraft). However, } \\
\text { fund still becomes a problem, } \\
\text { trying to find } \\
\text { other sources of } \\
\text { funding. }\end{array}$ \\
\hline Culture & $\begin{array}{l}\text { So far, there already have two } \\
\text { cultural tourism attractions/cultural } \\
\text { event can be performed (Reog } \\
\text { dance and Village Anniversary Day } \\
\text { Celebration) }\end{array}$ & $\begin{array}{l}\text { Revitalizing some } \\
\text { old traditions and } \\
\text { trying to create } \\
\text { new cultural } \\
\text { events. }\end{array}$ \\
\hline $\begin{array}{l}\text { The villagers already have good } \\
\text { tradition as their soft skills or local } \\
\text { wisdom; such as working together, } \\
\text { respect visitors, willingness to serve } \\
\text { and help and friendly. However, } \\
\text { most of them do not know much } \\
\text { about tourism and tourism business. } \\
\text { Furthermore, most of them do not } \\
\text { have ability in foreign language. }\end{array}$ & $\begin{array}{l}\text { The community } \\
\text { should be given } \\
\text { rertain training } \\
\text { business to tourism } \\
\text { English, and }\end{array}$ \\
\hline \multicolumn{2}{|c|}{} \\
\hline
\end{tabular}

Besides, a set of questionnaire was also given to the villagers to see directly their perspective related to their knowledge and readiness towards the plan for the development of the village to become a tourism village.
TABLE IX. THE RESUlT OF THE QUESTIONNAIRE FROM BRANCAH VILLAGE

\begin{tabular}{|l|l|}
\hline Rated Aspect & \multicolumn{1}{|c|}{ Description } \\
\hline Understanding & $\begin{array}{l}\text { The community already knows about the tourist village. } \\
\text { This was also conveyed by the head of Brancah Village } \\
\text { in every meeting to the community. The village } \\
\text { Government has begun to socialize the planning to } \\
\text { develop Brancah into a tourist village. They really } \\
\text { support the development of Brancah Village into a } \\
\text { tourist village. They argued this program can improve } \\
\text { their economy by selling around tourist object. }\end{array}$ \\
\hline $\begin{array}{l}\text { Community } \\
\text { Readiness }\end{array}$ & $\begin{array}{l}\text { The community will be ready and take an active role to } \\
\text { participate in the development of tourism object } \\
\text { planning and the development of their village into a } \\
\text { tourist village. The community is ready to assist every } \\
\text { activity that will be done by the village government for } \\
\text { this program. They will provide good service to the } \\
\text { visitors who will visit the tourist attraction in this } \\
\text { village. They are also ready to learn and speak English } \\
\text { as one tolls of international communication. }\end{array}$ \\
\hline
\end{tabular}

1) Result of PRA related to community readiness in developing tourism village: Participatory Rural Appraisal (PRA) is one of strategies used to empower the community. PRA focuses on the community participation in the plan to develop Berancah Village to become a tourism village. The result of Participatory Rural Appraisal of Berancah Village is stated in the following table 9 above.

\section{CONCLUSION AND SUGGESTION}

\section{A. Conclusions}

- Berancah Village has potential natural tourism objects which is 'feasible' to be developed as a tourism village with $79.25 \%$. Furthermore, it also has some promising cultural tourism attractions or events to be developed.

- The community of Berancah Village will be ready to get involve together with the government in developing the village to become a tourism village.

\section{B. Suggestion}

Beside the local (village) government and the community, one most important stakeholder is the regional government of Bengkalis Regency itself. Therefore, full support from the Bengkalis Regency government is needed by Berancah Village in their development to become a tourism village.

\section{REFERENCES}

[1] Dirjen PHKA, Pedoman Analisis Daerah Operasi Obyek dan Daya Tarik Wisata Alam (ADO-ODTWA). Bogor: Directorate General of Forest Protection and Nature Conservation Ministry of Forestry, 2003.

[2] O.A. Yoeti, Pengantar Ilmu Pariwisata. Bandung: Angkasa, 1996.

[3] R.G. Soekadijo, Anatomi Pariwisata Memahami Pariwisata Sebagai Systemic Link age. Jakarta: PT. Gramedia Pustaka Utama, 2000.

[4] D. Sawitri, Pengaruh Faktor Produktivitas Terhadap Kinerja Dan Nilai Tambah Pada Industri Kecil Makanan Di Jawa Timur (Doctora dissertation, UNIVERSITAS AIRLANGGA), 2004. 